\title{
Response of Liquid Biofertilizers (Bradyrhizobium and PSB) on Nutrient Content in Soybean (Glycine max L.)
}

\author{
Daravath Raja $^{1 *}$ and V. G. Takankhar ${ }^{2}$ \\ ${ }^{1}$ Department of Soil Science and Agricultural Chemistry, College of Agriculture, Latur, \\ V.N.M.K.V. Parbhani, India \\ ${ }^{2}$ Department of Soil Science and Agricultural Chemistry, Programme Coordinator, KVK, \\ Tuljapur, Dist-Osmanabad, V.N.M.K.V. Parbhani, India \\ *Corresponding author
}

\section{A B S T R A C T}

\section{Keywords \\ Liquid Bio-fertilizers, Bradyrhizobium, PSB, \\ Soybean, Nutrient content in plant \\ Article Info \\ Accepted: \\ 26 April 2018 \\ Available Online: \\ 10 May 2018}

\begin{abstract}
A field experiment was carried out on "Nutrient content in soybean plants as influenced by liquid biofertilizers (Bradyrhizobium and PSB)". It was conducted in Kharif season during the year 2013-14 at the research farm of Oil Seed Research Station, Latur, Maharashtra, in factorial randomized block design with three replications and variety MAUS-81 as a test crop along with 16 treatment combination containing four levels of liquid Bradyrhizobium $(0 \mathrm{ml}, 5 \mathrm{ml}, 10 \mathrm{ml}$, and $15 \mathrm{ml})$ and four levels of liquid PSB $(0 \mathrm{ml}, 5 \mathrm{ml}, 10 \mathrm{ml}$, and $15 \mathrm{ml})$. Nitrogen content in plant was significantly increased by seed inoculation with liquid $10 \mathrm{ml}$ of Bradyrhizobium $\left(\mathrm{A}_{2}\right)$ at maturity $7.93 \%$ and at harvest $3.62 \%$ over control. Phosphorus content was significantly improved (at maturity $28.57 \%$ and at harvest $31.25 \%$ ) by seed inoculation with liquid $10 \mathrm{ml}$ of PSB $\left(\mathrm{B}_{2}\right)$ over control.
\end{abstract}

\section{Introduction}

Soybean (Glycine max) a leguminous crop originated in China. It is basically a pulse crop and gained the importance as an oil seed crop as it contains $20 \%$ cholesterol free oil. It posses a very high nutritional value, and contains 40 per cent high quality protein due to this reason, soybean is known as 'poor man's meat'. India stands next only to China in the Asia pacific region, with respect to production (12.9 m.t). Maharashtra is the second largest producer in India, with $4.86 \mathrm{~m} . \mathrm{t}$ of production (Anonymous, 2013). Soybean played a key role in the yellow revolution. It is newly introduced and commercially exploited crop in India. Soybean has been playing an important role in national economy by earning an average of Rs. 32,000 million per annum through export of soy meal and contributing about $18 \%$ to the edible oil production (Anonymous, 2012).

The prices of fertilizers are increasing day by day and therefore, it is necessary to reduce the cost of fertilizers by using Bradyrhizobium and PSB inoculation to increase yield of legume crops. Biofertilizers cannot replace chemical fertilizers, but certainly are capable of reducing their input. Seed inoculation with effective Bradyrhizobium inoculant is recommended to ensure adequate nodulation and $\mathrm{N}_{2}$ fixation for maximum growth and yield of pulse crop. Biofertilizer do not supply nutrients directly to crop plants but have capacity to fix atmospheric nitrogen and convert insoluble phosphate into soluble form. Hence, soil microorganisms play significant role in mobilizing $\mathrm{P}$ for the use of plant and large fraction of soil 
microbial population can dissolve insoluble phosphate in soil.

Dhage and Kachhave (2008) conducted research work on effect of dual inoculation of Rhizobium and PSB on yield, nutrient content, availability of nutrients and quality of soybean [Glycine max (L.) Merrill] and they observed at flowering stage the highest $\mathrm{N}(3.13 \%), \mathrm{P}(2.05 \%)$, and $\mathrm{K}(2.13 \%)$ and at harvest stage $\mathrm{N}, \mathrm{P}$ and $\mathrm{K}$ contents of $6.23,2.68$ and 2.29 per cent were recorded in $100 \% \mathrm{RDF}+$ Rhizobium + PSB treatment, respectively.

\section{Materials and Methods}

The field experiment was conducted in Kharif season during the year 2013-14 at the research farm of Oil Seed Research Station, Latur, Maharashtra, geographically situated between $18^{0}$ $05^{\prime}$ to $18^{0} 75^{\prime} \mathrm{N}$ latitude and between $76^{0} 25^{\prime}$ to $77^{0} 36^{\prime}$ E longitude on the Deccan plateau with height mean sea level (MSL) about 633.85 meters and average rainfall is $750-800 \mathrm{~mm}$. The experimental soil was deep black in color with good drainage, moderate calcareous in nature and moderate alkaline in reaction with $\mathrm{pH}(1: 2.5)$ 8.30, EC (1:2.5) $0.36 \mathrm{dSm}^{-1} \mathrm{CaCO}_{3}(5.03 \%)$ and organic C $\left(5.4 \mathrm{~g} \mathrm{~kg}^{-1}\right)$ The available soil $\mathrm{N}, \mathrm{P}, \mathrm{K}$ and $\mathrm{S}$ were $131.20,19.68, \quad 597.9, \quad 15.35 \mathrm{kgha}^{-1}$ respectively.

Soybean was grown in factorial randomized block design with three replications and variety MAUS81 as a test crop along with 16 treatment combination containing four levels of liquid Bradyrhizobium $(0 \mathrm{ml}, 5 \mathrm{ml}, 10 \mathrm{ml}$, and $15 \mathrm{ml})$ and four levels of liquid PSB $(0 \mathrm{ml}, 5 \mathrm{ml}, 10 \mathrm{ml}$, and $15 \mathrm{ml})$.

Soybean seed after inoculation with required quantity of liquid biofertilizers viz. Bradyrhizobium and PSB was sown at spacing 45 $\times 5 \mathrm{~cm} @ 75 \mathrm{~kg} \mathrm{ha}^{-1}$ in 4th July, 2013. A uniform dose of fertilizers (30:60:30:30 $\mathrm{kg} \mathrm{ha}^{-1}$ of $\mathrm{N}, \mathrm{P}_{2} \mathrm{O}_{5}$, $\mathrm{K}_{2} \mathrm{O}, \mathrm{S}$ ) were supplied through urea, SSP, MOP and bensulph before sowing. Hand weeding was carried out at 26 DAS first spray of Chloropyriphos $25 \mathrm{ml} / 10$ lit water, bavistin 20 $\mathrm{gm} / 10$ lit water at time of incidence of insect pests (30DAS) and second of proclaim (benzoet) $15 \mathrm{gm} / 10$ lit of water at in 30 days interval of first spray. The crop was harvested on 15 Oct. 2013.

\section{Results and Discussion}

\section{Concentration of nutrients in plant}

In order to study the impact of different levels of liquid Bradyrhizobium and PSB on nutrient content in soybean, plant samples were analyzed for $\mathrm{N}, \mathrm{P}, \mathrm{K}$ and $\mathrm{S}$ and result presented here.

\section{Concentration of nitrogen}

The $\mathrm{N}$ content in soybean plant was not influenced significantly by liquid Bradyrhizobium at branching, flowering and pod formation stages but it was significantly influenced at maturity and at harvest stages (Table 1). The higher $\mathrm{N}$ content in soybean was recorded due to the treatment $\mathrm{A}_{2}$ (10ml of Bradyrhizobium japonicum $\mathrm{kg}^{-1}$ seed) at branching, flowering and pod formation stages. The treatment $\mathrm{A}_{2}$ (10ml of Bradyrhizobium japonicum $\mathrm{kg}^{-1}$ seed) recorded significantly higher $\mathrm{N}$ content over $\mathrm{A}_{0}$ and $\mathrm{A}_{1}$ treatments at maturity and at harvest stages of soybean. However the treatments $\mathrm{A}_{0}$ (control) and $\mathrm{A}_{1} \quad(5 \mathrm{ml}$ Bradyrhizobium japonicum $\mathrm{kg}^{-1}$ seed) as well as $\mathrm{A}_{2}$ (10ml Bradyrhizobium japonicum $\mathrm{kg}^{-1}$ seed) and $\mathrm{A}_{3}\left(15 \mathrm{ml}\right.$ Bradyrhizobium japonicum $\mathrm{kg}^{-1}$ seed) were on par with each other. Among the different stages of soybean crop at branching stage $\mathrm{N}$ content in soybean plant was higher followed by flowering, pod formation and maturity stages and it was lower at harvest stage of soybean. This might be due to the fact that Rhizobium inoculation increased the root nodulation through better root development and more nutrient availability, resulting in better absorption and utilization of all plant nutrients, thus resulted in to more $\mathrm{N}$ and $\mathrm{P}$ content and uptake in seed and straw. Similar finding also reported by Singh et al., (2007).

Nitrogen content of soybean was not influenced significantly due to different PSB levels presented in table 1. However higher $\mathrm{N}$ content in soybean was recorded with the treatment $\mathrm{B}_{2}$ (10ml of PSB $\mathrm{kg}^{-1}$ seed) at all the growth stages of soybean crop.

The interaction effect between liquid Bradyrhizobium and PSB $(\mathrm{A} \times \mathrm{B})$ on $\mathrm{N}$ concentration in soybean plant was not significant. The treatment $A_{2} B_{2}$ was not significant but it gave maximum $\mathrm{N}$ content at all the growth stages of 
soybean crop. However dual as well as multi inoculation of biofertilizers with or without FYM statistically increased the uptake of $\mathrm{N}$ and $\mathrm{P}$. This might be attributed to enhanced activity of nitrogenase and nitrate-reductase enzyme in the soil (Oad et al., 2002).

\section{Concentration of phosphorus}

The data on P content in soybean as influenced by different levels of liquid Bradyrhizobium and PSB are presented in table 2. Phosphorus content of soybean was not influenced significantly due to different liquid Bradyrhizobium levels but the higher $\mathrm{P}$ content in soybean was recorded under the treatment $\mathrm{A}_{2}$ (10ml of Bradyrhizobium $\mathrm{kg}^{-1}$ seed) at all the growth stages of soybean crop.

The $\mathrm{P}$ content in soybean was not influenced significantly by liquid PSB at branching, flowering and pod formation stages but it was significantly influenced at maturity and harvest stages (Table $2)$. The higher $P$ concentration in soybean was recorded under the treatment $B_{2}(10 \mathrm{ml}$ of PSB kg-1 seed) at branching, flowering and pod formation stages. The treatment $\mathrm{B}_{2}(10 \mathrm{ml}$ of PSB kg-1 seed) recorded significantly higher $\mathrm{P}$ content over $\mathrm{B}_{0}$ and $\mathrm{B}_{1}$ treatments at maturity and harvest stages of soybean.

The treatments $\mathrm{B}_{0}$ (control) and $\mathrm{B}_{1}\left(5 \mathrm{ml}\right.$ PSB kg${ }^{-1}$ seed) as well as $B_{2}\left(10 \mathrm{ml} \mathrm{PSB} \mathrm{kg}^{-1}\right.$ seed) and $B_{3}$ $\left(15 \mathrm{ml} \mathrm{PSB} \mathrm{kg}^{-1}\right.$ seed) were at par with each other. It was also noticed that the higher concentration of phosphorus in plant in presence of biofertilizers was found at branching stage of crop and there after gradually decreased $\mathrm{P}$ content in plant decreased with advancement of crop growth. It might be due to dilution effect of nutrient at later growth stages of soybean. Secondly more nutrients are translocated for reproductive process of crop growth.

The higher concentration of phosphorus at branching might be due to the ability of PSB to transform insoluble phosphate in soil in to soluble forms by screating organic acids resulting in effective solubilization and utilization of phosphate. Inoculation of PSB alone increased the concentration of phosphorus in plant. Dubey (1997) found that phosphate solubilizing microorganisms play a major role in the solubilization and uptake of native and applied soil phosphorus.

The interaction effect between liquid Bradyrhizobium and PSB $(\mathrm{A} \times \mathrm{B})$ on $\mathrm{P}$ concentration in soybean plant was nonsignificant. The combined treatment $\mathrm{A}_{2} \mathrm{~B}_{2}(10 \mathrm{ml}$ of

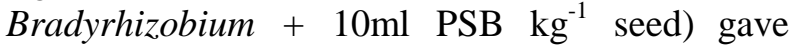
maximum $\mathrm{P}$ content at all the growth stages of soybean crop. However dual as well as multi inoculation of biofertilizers with or without FYM statistically increased the concentration of $\mathrm{N}$ and P. This might be attributed to enhanced activity of nitrogenase and nitrate-reductase enzyme in the soil (Purbey and Sen 2007), leading to greater biological nitrogen fixation by Rhizobium and increased availability of $\mathrm{P}$ in the soil due to greater solubilization of phosphate compound by phosphate solubilizing bacteria.

\section{Concentration of potassium}

The data regarding $\mathrm{K}$ content in soybean as influenced by different levels of liquid Bradyrhizobium and PSB are presented in table 3. Potassium content in soybean was not influenced significantly due to different liquid Bradyrhizobium levels but the higher $\mathrm{K}$ content in soybean was recorded with the treatment $\mathrm{A}_{2}(10 \mathrm{ml}$ of Bradyrhizobium $\mathrm{kg}^{-1}$ seed) at all the growth stages of soybean crop.

The data indicated that the difference in $\mathrm{K}$ content due to different liquid PSB levels were not reach to the level of significance except branching stage. Maximum and minimum $\mathrm{K}$ content (Table 3) was recorded with $B_{2}\left(10 \mathrm{ml} \mathrm{PSB} \mathrm{kg}^{-1}\right.$ seed) and $\mathrm{B}_{0}$ (control) at all the growth stages of soybean. The interaction effect between liquid Bradyrhizobium and PSB $(\mathrm{A} \times \mathrm{B})$ on $\mathrm{K}$ concentration in soybean plant was failed to reach the levels of significance. The combined treatment $\mathrm{A}_{2} \mathrm{~B}_{2} \quad(10 \mathrm{ml}$ of Bradyrhizobium $+10 \mathrm{ml} \mathrm{PSB} \mathrm{kg}^{-1}$ seed) was not significant but it gave maximum $\mathrm{K}$ content at all the growth stages of soybean crop. 
Table.1 Effect of liquid bio-fertilizers on $\mathrm{N}$ content at various critical growth stages of soybean

\begin{tabular}{|c|c|c|c|c|c|}
\hline \multirow[t]{2}{*}{ Treatments } & \multicolumn{5}{|c|}{$\mathbf{N}$ content $(\%)$ in plant } \\
\hline & branching & flowering & pod formation & maturity & harvest \\
\hline \multicolumn{6}{|c|}{ Rhizobium levels (A) } \\
\hline $\mathrm{A}_{0}(0 \mathrm{ml})$ & 2.70 & 2.40 & 2.32 & 2.27 & 2.21 \\
\hline $\mathrm{A}_{1}(5 \mathrm{ml})$ & 2.77 & 2.47 & 2.39 & 2.29 & 2.23 \\
\hline $\mathrm{A}_{2}(10 \mathrm{ml})$ & 2.91 & 2.61 & 2.53 & 2.45 & 2.29 \\
\hline $\mathrm{A}_{3}(15 \mathrm{ml})$ & 2.85 & 2.55 & 2.48 & 2.39 & 2.27 \\
\hline S.Em \pm & 0.06 & 0.07 & 0.06 & 0.01 & 0.02 \\
\hline $\mathrm{CD}$ at $5 \%$ & NS & NS & NS & 0.04 & 0.42 \\
\hline \multicolumn{6}{|l|}{ PSB levels (B) } \\
\hline $\mathrm{B}_{0}(0 \mathrm{ml})$ & 2.74 & 2.44 & 2.36 & 2.26 & 2.23 \\
\hline $\mathrm{B}_{1}(5 \mathrm{ml})$ & 2.79 & 2.49 & 2.41 & 2.38 & 2.24 \\
\hline $\mathrm{B}_{2}(10 \mathrm{ml})$ & 2.86 & 2.56 & 2.48 & 2.44 & 2.28 \\
\hline $\mathrm{B}_{3}(15 \mathrm{ml})$ & 2.85 & 2.55 & 2.47 & 2.40 & 2.28 \\
\hline S.Em \pm & 0.06 & 0.07 & 0.06 & 0.01 & 0.02 \\
\hline $\mathrm{CD}$ at $5 \%$ & NS & NS & NS & NS & NS \\
\hline \multicolumn{6}{|c|}{ Interaction $(\mathbf{A} \times \mathbf{B})$} \\
\hline S.Em \pm & 0.13 & 0.14 & 0.12 & 0.02 & 0.04 \\
\hline CD at $5 \%$ & NS & NS & NS & NS & NS \\
\hline
\end{tabular}

Table.2 Effect of liquid bio-fertilizers on P content at various critical growth stages of soybean

\begin{tabular}{|c|c|c|c|c|c|}
\hline \multirow[t]{2}{*}{ Treatments } & \multicolumn{5}{|c|}{$P$ content $(\%)$ in plant } \\
\hline & branching & flowering & pod formation & maturity & harvest \\
\hline \multicolumn{6}{|c|}{ Rhizobium levels (A) } \\
\hline $\mathrm{A}_{0}(0 \mathrm{ml})$ & 0.49 & 0.47 & 0.42 & 0.35 & 0.31 \\
\hline $\mathrm{A}_{1}(5 \mathrm{ml})$ & 0.50 & 0.48 & 0.43 & 0.38 & 0.34 \\
\hline $\mathrm{A}_{2}(10 \mathrm{ml})$ & 0.53 & 0.51 & 0.46 & 0.42 & 0.39 \\
\hline $\mathrm{A}_{3}(15 \mathrm{ml})$ & 0.52 & 0.50 & 0.45 & 0.41 & 0.38 \\
\hline S.Em \pm & 0.06 & 0.03 & 0.02 & 0.02 & 0.04 \\
\hline $\mathrm{CD}$ at $5 \%$ & NS & NS & NS & NS & NS \\
\hline \multicolumn{6}{|l|}{ PSB levels (B) } \\
\hline $\mathrm{B}_{0}(0 \mathrm{ml})$ & 0.50 & 0.47 & 0.43 & 0.35 & 0.32 \\
\hline $\mathrm{B}_{1}(5 \mathrm{ml})$ & 0.51 & 0.48 & 0.44 & 0.36 & 0.33 \\
\hline $\mathrm{B}_{2}(10 \mathrm{ml})$ & 0.53 & 0.50 & 0.46 & 0.45 & 0.42 \\
\hline $\mathrm{B}_{3}(15 \mathrm{ml})$ & 0.53 & 0.50 & 0.46 & 0.40 & 0.37 \\
\hline S.Em \pm & 0.06 & 0.03 & 0.02 & 0.02 & 0.04 \\
\hline $\mathrm{CD}$ at $5 \%$ & NS & NS & NS & 0.05 & 0.06 \\
\hline \multicolumn{6}{|c|}{ Interaction $(\mathbf{A} \times \mathbf{B})$} \\
\hline S.Em \pm & 0.02 & 0.06 & 0.04 & 0.04 & 0.08 \\
\hline CD at $5 \%$ & NS & NS & NS & NS & NS \\
\hline
\end{tabular}


Table.3 Effect of liquid bio-fertilizers on K content at various critical growth stages of soybean

\begin{tabular}{|c|c|c|c|c|c|}
\hline \multirow[t]{2}{*}{ Treatments } & \multicolumn{5}{|c|}{$K$ content $(\%)$ in plant } \\
\hline & branching & flowering & pod formation & maturity & harvest \\
\hline \multicolumn{6}{|c|}{ Rhizobium levels (A) } \\
\hline $\mathrm{A}_{0}(0 \mathrm{ml})$ & 2.36 & 2.02 & 1.61 & 1.50 & 1.35 \\
\hline $\mathrm{A}_{1}(5 \mathrm{ml})$ & 2.43 & 2.09 & 1.68 & 1.57 & 1.42 \\
\hline $\mathrm{A}_{2}(10 \mathrm{ml})$ & 2.57 & 2.23 & 1.82 & 1.71 & 1.56 \\
\hline $\mathrm{A}_{3}(15 \mathrm{ml})$ & 2.52 & 2.18 & 1.77 & 1.66 & 1.51 \\
\hline S.Em \pm & 0.06 & 0.07 & 0.06 & 0.08 & 0.06 \\
\hline $\mathrm{CD}$ at $5 \%$ & NS & NS & NS & NS & NS \\
\hline \multicolumn{6}{|l|}{ PSB levels (B) } \\
\hline $\mathrm{B}_{0}(0 \mathrm{ml})$ & 2.40 & 2.06 & 1.65 & 1.54 & 1.39 \\
\hline $\mathrm{B}_{1}(5 \mathrm{ml})$ & 2.45 & 2.11 & 1.70 & 1.59 & 1.44 \\
\hline $\mathrm{B}_{2}(10 \mathrm{ml})$ & 2.52 & 2.18 & 1.77 & 1.66 & 1.51 \\
\hline $\mathrm{B}_{3}(15 \mathrm{ml})$ & 2.51 & 2.17 & 1.76 & 1.65 & 1.50 \\
\hline S.Em \pm & 0.06 & 0.07 & 0.06 & 0.08 & 0.06 \\
\hline $\mathrm{CD}$ at $5 \%$ & NS & NS & NS & NS & NS \\
\hline \multicolumn{6}{|c|}{ Interaction $(\mathbf{A} \times \mathbf{B})$} \\
\hline S.Em \pm & 0.12 & 0.14 & 0.12 & 0.16 & 0.12 \\
\hline CD at $5 \%$ & NS & NS & NS & NS & NS \\
\hline
\end{tabular}

Table.4 Effect of liquid bio-fertilizers on S content at various critical growth stages of soybean

\begin{tabular}{|c|c|c|c|c|c|}
\hline \multirow[t]{2}{*}{ Treatments } & \multicolumn{5}{|c|}{ S content $(\%)$ in plant } \\
\hline & branching & flowering & pod formation & maturity & harvest \\
\hline \multicolumn{6}{|c|}{ Rhizobium levels (A) } \\
\hline $\mathrm{A}_{0}(0 \mathrm{ml})$ & 0.45 & 0.43 & 0.37 & 0.35 & 0.33 \\
\hline $\mathrm{A}_{1}(5 \mathrm{ml})$ & 0.46 & 0.44 & 0.38 & 0.36 & 0.34 \\
\hline $\mathrm{A}_{2}(10 \mathrm{ml})$ & 0.49 & 0.47 & 0.41 & 0.39 & 0.37 \\
\hline $\mathrm{A}_{3}(15 \mathrm{ml})$ & 0.48 & 0.46 & 0.40 & 0.38 & 0.36 \\
\hline S.Em \pm & 0.01 & 0.02 & 0.01 & 0.03 & 0.02 \\
\hline $\mathrm{CD}$ at $5 \%$ & NS & NS & NS & NS & NS \\
\hline \multicolumn{6}{|l|}{ PSB levels (B) } \\
\hline $\mathrm{B}_{0}(0 \mathrm{ml})$ & 0.46 & 0.43 & 0.38 & 0.35 & 0.33 \\
\hline $\mathrm{B}_{1}(5 \mathrm{ml})$ & 0.47 & 0.44 & 0.39 & 0.36 & 0.34 \\
\hline $\mathrm{B}_{2}(10 \mathrm{ml})$ & 0.49 & 0.46 & 0.41 & 0.38 & 0.36 \\
\hline $\mathrm{B}_{3}(15 \mathrm{ml})$ & 0.49 & 0.46 & 0.41 & 0.38 & 0.36 \\
\hline S.Em \pm & 0.01 & 0.02 & 0.01 & 0.03 & 0.02 \\
\hline $\mathrm{CD}$ at $5 \%$ & NS & NS & NS & NS & NS \\
\hline \multicolumn{6}{|c|}{ Interaction $(\mathbf{A} \times \mathbf{B})$} \\
\hline S.Em \pm & 0.02 & 0.04 & 0.02 & 0.06 & 0.04 \\
\hline CD at $5 \%$ & NS & NS & NS & NS & NS \\
\hline
\end{tabular}

Disintegration of $\mathrm{K}$ minerals due to release of organic acids by bioinoculants used for seed inoculation purpose. It was also noticed that dual inoculation of Rhizobium + PSB showed its superiority over single inoculation of PSB and Rhizobium. These results are in line with the finding of Sharma and Namdeo (1999) found seed 
inoculation with Rhizobium and PSB in presence of FYM gave higher N, P and K contents in plant and seed.

\section{Concentration of sulphur}

Data indicating concentration of sulphur recorded at branching, flowering, pod formation, maturity and at harvest was presented in table 4. It was evident from the results that the concentration of sulphur was not affected due to individual seed treatment with Bradyrhizobium and PSB levels. Sulphur content in soybean was not influenced significantly due to levels of liquid Bradyrhizobium and PSB. The higher S content was recorded under the treatments $A_{2}(10 \mathrm{ml}$ of Bradyrhizobium $\mathrm{kg}^{-1}$ seed) and $\mathrm{B}_{2}(10 \mathrm{ml}$ of PSB $\mathrm{kg}^{-1}$ seed) at all the growth stages of soybean. Normally lower $\mathrm{S}$ content was observed with $\mathrm{A}_{0}$ and $\mathrm{B}_{0}$ (control) treatment at all the growth stages of soybean.

The higher content of $S$ in seed and straw together with increased seed and straw yield might be the result of greater uptake of sulphur. These results are in agreement with those of Tomar (2011).

The interaction effect between liquid Bradyrhizobium and PSB $(\mathrm{A} \times \mathrm{B})$ on $\mathrm{S}$ concentration in soybean was failed to reach the levels of significance. The treatment $A_{2} B_{2}(10 \mathrm{ml}$ of Bradyrhizobium $+10 \mathrm{ml} \mathrm{PSB} \mathrm{kg}{ }^{-1}$ seed) was not significant but it gave maximum $\mathrm{S}$ content at all the growth stages of soybean crop.

\section{References}

Anonymous (2012).Soybean basic introduction. w.w.w.pnbkrishi.com/soybean.htm.

Anonymous (2013). Soybean Processors Association of India.w.w.w.sopa.org.

Chandra, R. (2006) Rhizobium inoculation in urdbean and its residual effect on wheat. Indian J. Pulses Res., 19 (2): 213-215.
Dhage, S.J., and Kachhave, K. G. (2008). Effect of dual inoculation of Rhizobium and PSB on yield, nutrient content, availability of nutrients and quality of soybean [Glycine $\max (\mathrm{L}$.$) Merrill].$ An Asian J. Soil Sci., 3 (2): 272-276.

Dubey, S.K. (1997). Co-inoculation of phosphorus solubilizing bacteria with Bradyrhizobium japonicum to increase phosphate availability to rainfed soybean on Vertisol. J. Indian Soc. Soil Sci., 45 (3):506-509.

Oad, F.C., Kumar, L. and Biswas, J.K. (2002). Effect of Rhizobium japonicum inoculum doses (liquid culture) on the growth and seed yield of soybean crop. Asian J. Plant Sci., 1 (4): 340342.

Pratibha Sahai and Ramesh Chandra (2011). Performance of liquid and carrier-based inoculats of Mesorhizobium ciceri and PGPR (Pseudomonas diminuta) in Chickpea (Cicer arietinum L.) on nodulation yield and soil properties. J. Indian Soc. Soil Sci. 59 (3): 263267.

Purbey, S.K. and Sen, N.L. (2007). Effect of bioinoculants and bioregulators on yield and nutrient uptake by fenugreek. Indian J. Agric. Res., 41 (2): 154-156.

Sharma, K.N. and Namdeo (1999). Effect of biofertilizers and phosphorus on growth and yield of soybean, J. Crop Res. 17 (2): 160-163.

Singh, S.R., Najar, G.R. and Ummed Singh (2007). Productivity and nutrient uptake of soybean (Glycine $\max (L)$.$) as influenced by bio-$ inoculants and farmyard manure under rainfed conditions. Indian J. Agron., 52 (4): 325-329.

Thenua, O.V.S., Shivakumar, B.G. and Jitendra kumar, M. (2006). Effect of biofertilizers and phosphorous fertilization on nodulation pattern productivity and phosphorous uptake by summer mung (Vigna radiata). Biofertilizer Newsletter, 14 (2): 0.

Tomar, R.K.S. (2011). Effect of integration of biofertilizers and farm yard manure with inorganic fertilizers on productivity of soybean (Glycine max) in farmers' fields. J. Oilseed Res., 28 (20): 112-114.

\section{How to cite this article:}

Daravath Raja and Takankhar V. G. 2018. Response of Liquid Biofertilizers (Bradyrhizobium and PSB) on Nutrient Content in Soybean (Glycine max L.). Int.J.Curr.Microbiol.App.Sci. 7(05): 3701-3706. doi: https://doi.org/10.20546/ijcmas.2018.705.428 